faculty members, the biggest upset is not the decision itself but the fact that it was made without consulting them.

Veterinary researcher Richard Eberle, who was an administrative liaison for the study, believes that the affair might give the impression that the university is no longer a reliable research partner. He notes that two major proposals for OSU-based primate research, involving some of the same institutions, are pending at the NIH. The NIH Office of the Director said in a statement that institutions are expected "to complete NIH supported projects as requested, approved and funded".

The dispute comes during a time of heightened activity by animal-rights activists, including firebombings at two University of California campuses. Although few institutions have policies that prohibit primate research, not many are keen to establish new primate programmes, says Dario Ringach, a neurobiologist at the University of California, Los Angeles, who stopped working on primates because of pressure from activists. "It is changing the kind of work people will do in the future," he says. "If students come to me interested in primate research, I would tell them to think about other things."

Brendan Borrell

See Editorial, page 699.

money and were very popular with the national and international scientific user communities."

Walter says that legal and confidentiality issues prevent the board from disclosing the details of Lamb's sacking. "The board unanimously resolved this course of action for a number of reasons that included significant compliance and stakeholder relationship issues which had built up over the past year," she says. The synchrotron has secured operational funding until June 2012 and is working on plans for further expansion, she adds.

So far, neither the Victorian nor the national governments have intervened, saying that it is a matter for the board to resolve. Angry at this lack of action, the scientists and technicians at the synchrotron began limiting their work to 9 a.m. to 5 p.m. in late November, a crippling move for a facility that is booked to run 24 hours a day. Although they returned to normal schedules after Walter agreed to discuss their complaints, they now say that they will again work to rule unless Walter leaves.

The SAC has written to Victorian premier John Brumby protesting against Lamb's dismissal: "In our collective experience spanning decades and continents, no synchrotron director has ever been removed from office without notice."

Stephen Pincock

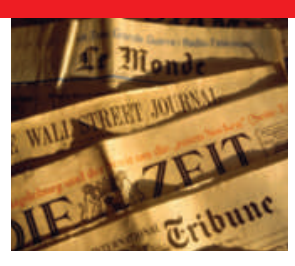

GOT ANEWS TIP?

Send any article ideas for Nature's News section to newstips@nature.com

\title{
'Killer application' for protein synthesis is retracted
}

The retraction of two papers from the lab of prominent US chemist Peter Schultz is a setback for researchers trying to synthesize and study glycoproteins proteins with sugar chains attached.

The papers, published in Science ${ }^{1}$ and the Journal of the American Chemical Society $^{2}$ (JACS), seemed to show that technology enabling the bacterium Escherichia coli to make proteins from many non-natural amino acids could also incorporate sugars at specific sites.

Schultz, of the Scripps Research Institute in La Jolla, California, says that while attempting to replicate the work in the two papers, members of his lab discovered that non-natural glycosylated amino acids - ones with attached sugars - behave differently from all other non-natural amino acids his lab has studied. The researchers were unable to get the specific amino acids described in the two papers to integrate into proteins, although they did manage to get the bacteria to make proteins incorporating other glycosylated amino acids, Schultz says. He and his colleagues retracted the JACS paper on 4 September ${ }^{3}$ and the Science paper on 27 November ${ }^{4}$.

In August, a paper co-authored by Eric Tippmann, a former postdoc of Schultz's who is now at Cardiff University, UK, argued that the method described in the papers could not have worked anyway ${ }^{5}$. E. coli, he reported, has insufficient levels of the relevant enzymes necessary to process the glycosylated amino acids that were used in the experiment. He and his colleagues suggest ${ }^{5}$ that the proteins reported in the retracted papers contained natural rather than non-natural glycosylated amino acids.

Schultz says it could be true that the proteins incorporated natural rather than non-natural amino acids, but adds that there are other possible explanations for his results.

He says that the conditions of the original experiments may have allowed the E. coli to process the glycosylated amino acids, which had been modified to allow them to enter the bacteria easily. However, the lab no longer has the notebooks detailing the original experiments, so the team can't replicate those conditions, Schultz explains.

Schultz says that he had members of his lab try to replicate the papers for more than two years. "We worked hard on it, and there are real peculiarities associated with the glycosylated amino acids that we still don't understand," Schultz says. "We couldn't get it to work." Only then did the team decide to retract the papers. "I think we did the right thing," says Schultz.

Glycoproteins are ubiquitous in biology and pharmacology, but difficult to make artificially in living cell systems, so the ability to direct bacteria to make specific glycoproteins would have been a boon.

Chemist David Tirrell of the California Institute of Technology in Pasadena, who also studies methods for incorporating non-natural amino acids into proteins, says the retractions will be a blow for glycobiologists. But because the glycobiology work was often seen as proof of principle, it is also a disappointment for anyone working on making proteins from non-natural amino acids, he says. "This

akes away one of the benchmarks people would cite to show how far the method could go," says Tirrell.

Another former postdoc of Schultz's, Ryan Mehl, who is now at Franklin \& Marshall College in Lancaster, Pennsylvania, agrees. "[Glycobiologists] went from something where they had the potential for great tools to zero, so it's a big deal for that field."

Schultz's underlying method for incorporating non-natural amino acids into proteins has been reproduced by other labs, note Tirrell, Mehl and other scientists. But the ability to incorporate glycoproteins "would have been a killer application", says Steven Benner of the Foundation for Applied Molecular Evolution in Gainesville, Florida. "I'm disappointed that it didn't work." Erika Check Hayden

\footnotetext{
. Zhang, Z. et al. Science 303, 371-373 (2004).

2. Xu, R. et al. J. Am. Chem. Soc. 126, 15654-15655 (2004).

Xu, R. et al. J. Am. Chem. Soc. 131, 13883 (2009)

4. Zhang, Z. et al. Science 326, 1187 (2009).

5. Antonczak, A. K., Simova, Z. \& Tippmann, E. M. J. Biol. Chem. 284, 28795-28800 (2009).
} 